Article

\title{
Origin of Reverse Zoned Cr-Spinels from the Paleoproterozoic Yanmenguan Mafic-Ultramafic Complex in the North China Craton
}

\author{
Yang Bai ${ }^{1,2, *}$, Ben-Xun Su ${ }^{1,2}$ (D), Yan Xiao ${ }^{3}$, Davide Lenaz ${ }^{4}$ (D), Patrick Asamoah Sakyi ${ }^{5, *(D)}$, \\ Zi Liang ${ }^{2,3}$, Chen Chen ${ }^{1,2}$ and Sai-Hong Yang ${ }^{3}$ \\ 1 Key Laboratory of Mineral Resources, Institute of Geology and Geophysics, Chinese Academy of Sciences, \\ P.O. Box 9825, Beijing 100029, China; subenxun@mail.iggcas.ac.cn (B.-X.S.); chenc@mail.iggcas.ac.cn (C.C.) \\ 2 University of Chinese Academy of Sciences, Beijing 100049, China; liangzi@mail.iggcas.ac.cn \\ 3 State Key Laboratory of Lithospheric Evolution, Institute of Geology and Geophysics, \\ Chinese Academy of Sciences, P.O. Box 9825, Beijing 100029, China; xiaoyan@mail.iggcas.ac.cn (Y.X.); \\ shyang@mail.iggcas.ac.cn (S.-H.Y.) \\ 4 Department of Mathematics and Geosciences, University of Trieste, Via Weiss 8, 34128 Trieste, Italy; \\ lenaz@units.it \\ 5 Department of Earth Science, School of Physical and Mathematical Sciences, University of Ghana, \\ P.O. Box LG 58, Legon-Accra, Ghana \\ * Correspondence: by@mail.iggcas.ac.cn (Y.B.); pasakyi@ug.edu.gh (P.A.S.); Tel.: 86-10-82998602 (Y.B.)
}

Received: 20 December 2017; Accepted: 8 February 2018; Published: 12 February 2018

\begin{abstract}
We conducted petrological and mineral chemistry investigations of $\mathrm{Cr}$-spinel in ultramafic rocks of the Yanmenguan mafic-ultramafic complex in the North China Craton. The Cr-spinel grains occur as inclusions in enstatite, tschermakite, phlogopite, and olivine, or as interstitial grains among the aforementioned silicate minerals, and show concentric or asymmetrical textures. Back-scattered electron and elemental images and compositional profiles of the spinel grains indicate the presence of $\mathrm{Cr}$ - and Fe-rich cores and $\mathrm{Al}$ - and $\mathrm{Mg}$-rich rims. The host silicate minerals display a decrease in $\mathrm{Al}$ and $\mathrm{Mg}$ contents accompanied by an increase in $\mathrm{Cr}$ and $\mathrm{Fe}$ away from the spinel. These textures and compositional variations suggest that subsolidus elemental exchange more likely gave rise to the compositional zonation, resulting in the transfer of $\mathrm{Al}$ and $\mathrm{Mg}$ from the silicate minerals to the spinel. The Mn, Ni, and Ti contents in spinel and the major elements of olivine-hosted spinel are relatively stable during subsolidus elemental diffusion and thus are more reliable tracers of primary high-temperature processes. The temperature estimates reveal that the subsolidus diffusion might have occurred at $600-720^{\circ} \mathrm{C}$, which could be linked to the regional metamorphic event.
\end{abstract}

Keywords: compositional zoning; spinel; elemental exchange; North China Craton

\section{Introduction}

Chromium-bearing spinels are stable and highly refractory minerals that are very resistant to alteration, weathering, and melt percolation, in comparison with paragenetic silicate minerals $[1,2]$. They are therefore good petrogenetic indicators of the source characteristics, evolution, and tectonic setting of magmas [3-6]. Nonetheless, they can occasionally display compositional zonation. The most common zoning texture in $\mathrm{Cr}$-spinels is characterized by $\mathrm{Al}$ - and $\mathrm{Mg}$-rich cores and $\mathrm{Cr}$ - and Fe-rich rims, referred to as "normal zonation" [7-9]. The normally zoned Cr-spinels have been reported in ophiolites [10], layered mafic-ultramafic complexes [11], komatiites [12], mantle xenoliths [13,14], and metamorphosed ultramafic massifs [15]. Their formation is generally ascribed to high temperature hydrothermal alteration [16] or metamorphism [15,17], evidenced by the presence of secondary phases such as chlorite and antigorite surrounding the Cr-spinel or relict magnetite $[15,18,19]$. 
Relative to normal zonation, reverse zoning texture in $\mathrm{Cr}$-spinel shows the opposite compositional feature, characterized by $\mathrm{Al}$ - and $\mathrm{Mg}$-rich rims and $\mathrm{Cr}$ - and Fe-rich cores. The reverse zoning texture in Cr-spinel has been reported in meteorites [20], mid-ocean ridge basalts (MORBs), [21] and various mafic-ultramafic complexes (e.g., Alpine-type [22]; layered [23]; Alaskan-type [24]). Although this type of texture has been investigated in some mineralogical [25], geochemical [22], and experimental [26,27] studies, its origin is still a matter of continuous debate. The texture has been interpreted as a product of fractional crystallization [21,25,28-32], reaction with non-homologous melt [33-36], and elemental exchange with host silicate minerals $[22,24,37]$.

In this study, we report reverse zoning texture in Cr-spinels from ultramafic rocks of the Yanmenguan mafic-ultramafic complex. The zoned-textured $\mathrm{Cr}$-spinel occurs as inclusions in a variety of silicate minerals or as interstitial grains among different silicate minerals, and the texture is variable from concentric to asymmetrical. Mineral morphology, elemental mapping images, and compositional profile analyses were employed to determine the mechanism and origin of the reverse zoning texture and its implications.

\section{Geology of the Yanmenguan Mafic-Ultramafic Complex}

The North China Craton is traditionally divided into two major continental blocks, the Western and Eastern Blocks, which are separated by a collision zone referred to as the Trans-North China Orogen (TNCO), and are composed of TTG (tonalite-trondhjemite-granodiorite) gneisses and granite-greenstone belts [38] (Figure 1a). The Hengshan-Wutai-Fuping area located in the central segment of this orogen is identified as an extensive exposure in the NCC (Figure 1b). Thereinto, abundant Neoarchean mafic-ultramafic boudins are distributed in the Wutai Group in a NE-SW direction, and separated by the Fuping terrane and Hengshan gneiss complex. All of these complexes are scattered within strongly deformed flysch-like metabasic and metapelitic rocks, which record the amphibolite- to granulite-facies metamorphism in the region [38]. Because of intensive metamorphic overprint [39], the origin and tectonic setting of these mafic-ultramafic rocks are disputed. Li et al. $[40,41]$ interpreted these mafic-ultramafic complexes as remnants of paleo-oceanic lithosphere. Wang et al. [39] identified them as a mélange of Neoarchean ophiolite, whereas Polat et al. [42] suggested that some of them formed in a forearc setting. Recently, Yanmenguan complex, one of these mafic-ultramafic complexes which was akin to Alaskan-type complex in aspects of mineral chemistry, greatly depended on the compositions of Cr-spinel and silicate minerals [43,44].

The Yanmenguan mafic-ultramafic complex is located in the northwest of the Hengshan-Wutai -Fuping area (Figure 1b). It cuts through the Neoarchean gneisses, and has a formation age of $2.2 \mathrm{Ga}$ (zircon $\mathrm{U}-\mathrm{Pb}$ dating; [43]). The complex occurs as lenses with a distinctive zoning pattern of peridotite, olivine pyroxenite, pyroxenite, hornblendite, and gabbro, in the order from center to margin (Figure 1c). The peridotite shows granoblastic or porphyroclastic textures and is mainly composed of olivine, enstatite, diopside, Cr-spinel, and tschermakite, with minor phlogopite, magnetite, and sulfides. Olivine grains occur as mainly cumulate minerals in variable sizes from 0.2 to $1 \mathrm{~mm}$ (Figure 2a,b), and occasionally display granular and equilibrated texture with nearly $120^{\circ}$ triple junctions (Figure 2c). All other minerals show subhedral or anhedral texture. Enstatite is the dominant intercumulus mineral, forming oikocrysts in the range of $0.1-0.5 \mathrm{~cm}$ in diameter. Diopside and tschermakite occur as large oikocrysts or small anhedral grains at the boundary of olivine grains. Olivine pyroxenite shows gradational contacts with the peridotite and consists mainly of enstatite, tschermakite, diopside, olivine, and Cr-spinel, with accessory phlogopite, chlorapatite, and magnetite (Figure $2 \mathrm{~d}-\mathrm{h}$ ). Enstatite and diopside are oikocrysts with sizes in the range of $0.2-1 \mathrm{~cm}$, whilst tschermakite is relatively small in size and less abundant. Olivine occurs as interstitial grains or as inclusions in enstatite, diopside, or tschermakite (Figure $2 \mathrm{~d}-\mathrm{g}$ ). The radial fractures in enstatite are exhibited for the differential contraction between encapsulated olivine and host enstatite during the cooling process (Figure 2h) [45]. Intercumulus tschermakite is present as the latest intercumulus voids or resorption-induced rim around the diopside (Figure 2i). Phlogopite in many places occurs with chlorapatite as inclusions in 
enstatite (Figure 2j). Cr-spinel is the most common accessory mineral in the ultramafic rocks and rarely occurs in the mafic rocks. It is euhedral to subhedral, ranging in size from 0.05 to $0.2 \mathrm{~mm}$, and occurs within or among silicate minerals. Apart from the opaque or green spinel (Figure 2k), zoning texture is commonly emphasized by the light brown core and greenish rim (Figure 21).
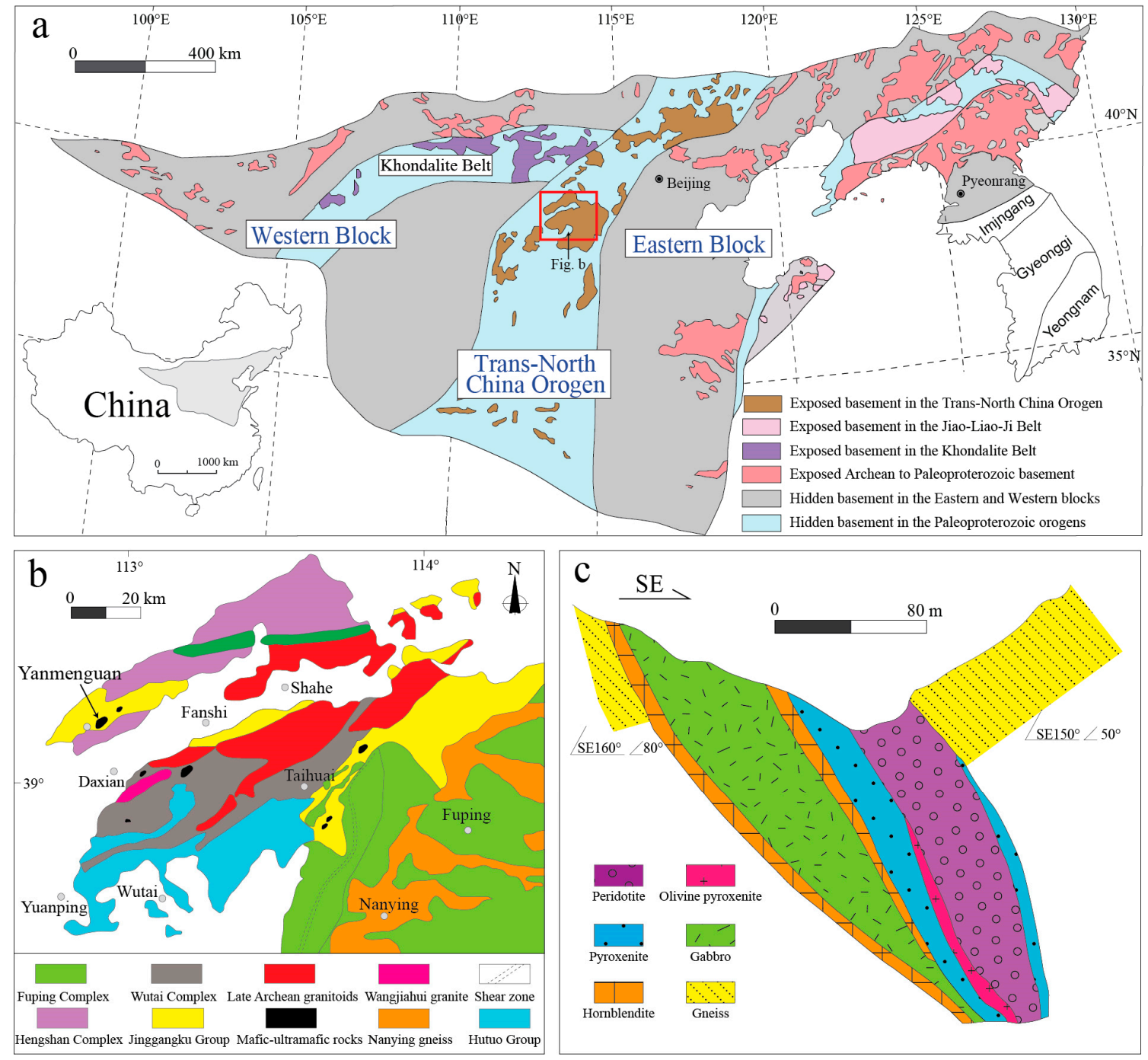

Figure 1. (a) Subdivisions of the North China Craton and location of the Yanmenguan mafic-ultramafic complex (modified after [38]). (b) Simplified geological map of the Hengshan-Wutai-Fuping area (modified after [43]). (c) Geological sketch map of the Yanmenguan complex, showing the major rock units of peridotite, olivine pyroxenite, pyroxenite, hornblendite, gabbro, and the surrounding Archean gneiss as a country rock. Note that the lithological units are zonal patterns in the vertical section (modified after [43]). 

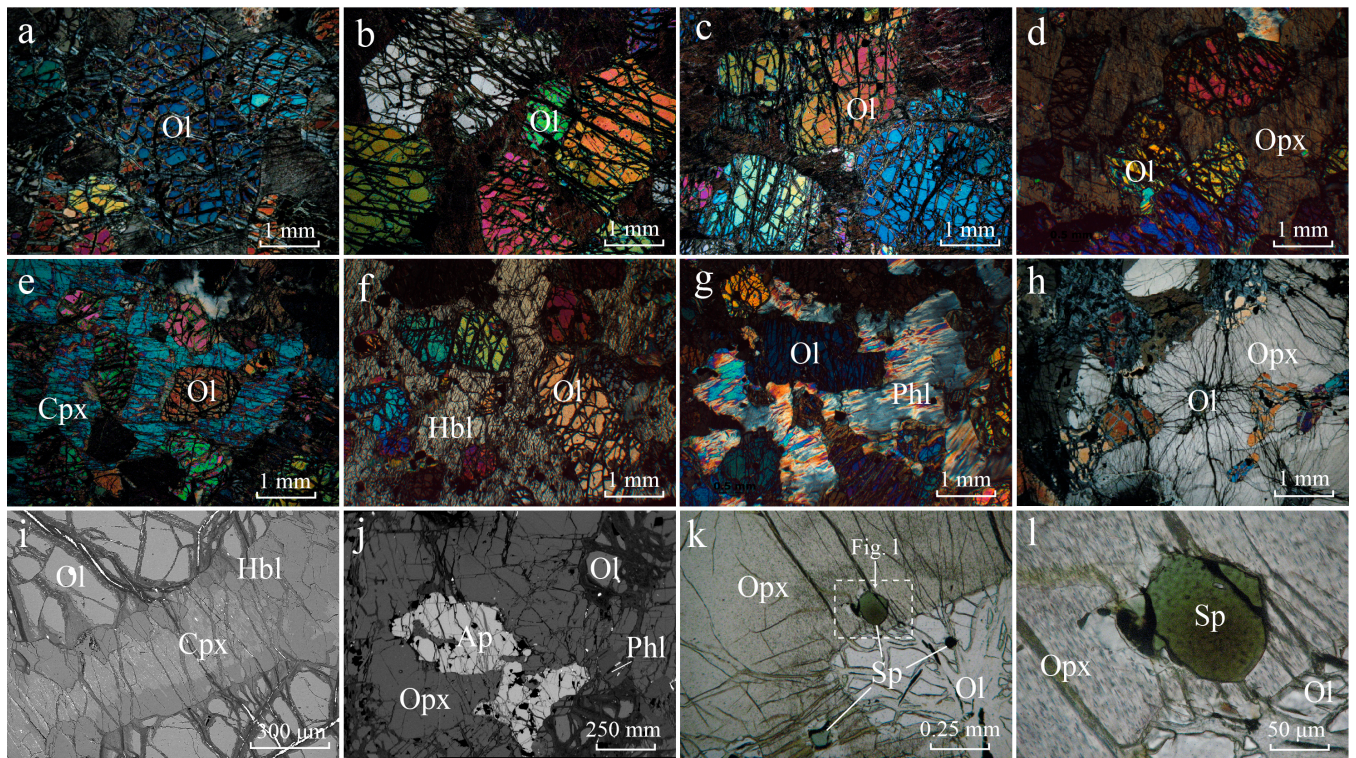

Figure 2. Polarized optical images and back-scattered electron images of ultramafic suits: (a-c) Olivine $(\mathrm{Ol})$ occurring as cumulate crystals and partially serpentinized; (d) Olivine crystals surrounded by enstatite (Opx); (e) Olivine crystals surrounded by diopside (Cpx); (f) Olivine surrounded by tschermakite ( $\mathrm{Hbl})$; (g) Olivine surrounded by phlogopite (Phl). (h) Enstatite-hosted olivine with radial fractures. (i) Resorption-induced rim of tschermakite around diopside (j) Chlorapatite (Ap)-phlogopite pairs; (k) Three different appearances of $\mathrm{Cr}$-spinel (Sp) in enstatite and olivine under polarizing microscope; (l) Zoned Cr-spinel under a polarizing microscope.

\section{Analytical Methods}

Polished thin sections of all the samples from the ultramafic rock suits were investigated by a FEI Nova nano450 scanning electron microscope (SEM), equipped with energy dispersive spectrometry (EDS) at the State Key Laboratory of Lithospheric Evolution, Institute of Geology and Geophysics, Chinese Academy of Sciences (IGGCAS), Beijing, China. High-resolution elemental mapping images were obtained at the working conditions of $20 \mathrm{kV}$ accelerating voltage and $3.5 \mathrm{nA}$ beam current, with a working distance of $4 \mathrm{~mm}$ from the polepiece to the sample surface.

For major elements, compositional profiles of minerals as well as back-scattered electron images were obtained by wavelength-dispersive spectrometry (WDS) using a JEOL JXA8100 electron probe at the State Key Laboratory of Lithospheric Evolution, IGGCAS, Beijing, China, operating at an accelerating voltage of $15 \mathrm{kV}, 12 \mathrm{nA}$ beam current, $5 \mu \mathrm{m}$ beam spot size, and 10-30 s dwell time as well as $11 \mathrm{~mm}$ working distance. The elements were acquired using three crystals as follows: LIFH for $\mathrm{Cr}, \mathrm{Mn}, \mathrm{Fe}$, and $\mathrm{Ni}$, PETJ for $\mathrm{K}, \mathrm{Ca}$, and $\mathrm{Ti}$, and TAP for $\mathrm{Na}, \mathrm{Mg}, \mathrm{Al}$, and $\mathrm{Si}$. The standards used were albite for $\mathrm{Na}$, diopside for $\mathrm{Si}, \mathrm{Ca}$, and $\mathrm{Mg}$, haematite and synthetic $\mathrm{Cr}_{2} \mathrm{O}_{3}$ for $\mathrm{Cr}$, synthetic $\mathrm{TiO}_{2}$ for $\mathrm{Ti}$, orthoclase for $\mathrm{K}$, synthetic $\mathrm{Al}_{2} \mathrm{O}_{3}$ for $\mathrm{Al}$, synthetic $\mathrm{MnO}$ for $\mathrm{Mn}$ and synthetic $\mathrm{NiO}$ for $\mathrm{Ni}$. $\mathrm{K}(\alpha)$ lines were selected for analysis, and the detection limits were in the range of $0.008 \sim 0.02 \mathrm{wt} \%$ $(1 \sigma)$. The spacing of points in the profiles was within 10 15 $\mu \mathrm{m}$ and traversed the Cr-spinel and paired silicates. Matrix effects were corrected by a program based on the ZAF procedure. $\mathrm{Fe}^{2+}-\mathrm{Fe}^{3+}$ redistribution from electron microprobe analyses was carried out using the general equation for estimating $\mathrm{Fe}^{3+}$ defined by Droop [46]. The profiles of reverse-zoned $\mathrm{Cr}$-spinel in and among different silicate minerals are provided in supplementary materials.

\section{Zoning Texture of Cr-Spinel}

Reverse zoning texture is commonly found in Cr-spinel inclusions in enstatite (Figure $3 a, b$ ), tschermakite (Figure 3c,d), phlogopite (Figure 3e) and olivine (Figure 3f), which are all from the 
ultramafic rocks in the Yanmenguan complex. Specifically, the concentric-reverse zonation shows a gradual variation from bright core to dark rim in back-scattered electron images, except for the uniqueness of olivine-hosted Cr-spinels with very thin rims relative to broad cores (Figure 3f). Interstitial Cr-spinel grain that occurs amongst different silicate minerals is also zoned with concentric texture (Figure 3g,h), except that the Cr-spinels among the olivine-Cr-spinel-enstatite (or tschermakite) arrangements display asymmetrical zonation (Figure 3i-1), with their cores usually restrict close to the direction of olivine. In addition, the occurrence of a cluster of $\mathrm{Cr}$-spinel indicates that zoning textures are well developed in larger grains, whilst some of the relatively small Cr-spinel grains hardly preserve any zoning texture (Figure $3 \mathrm{~m}-\mathrm{p}$ ).

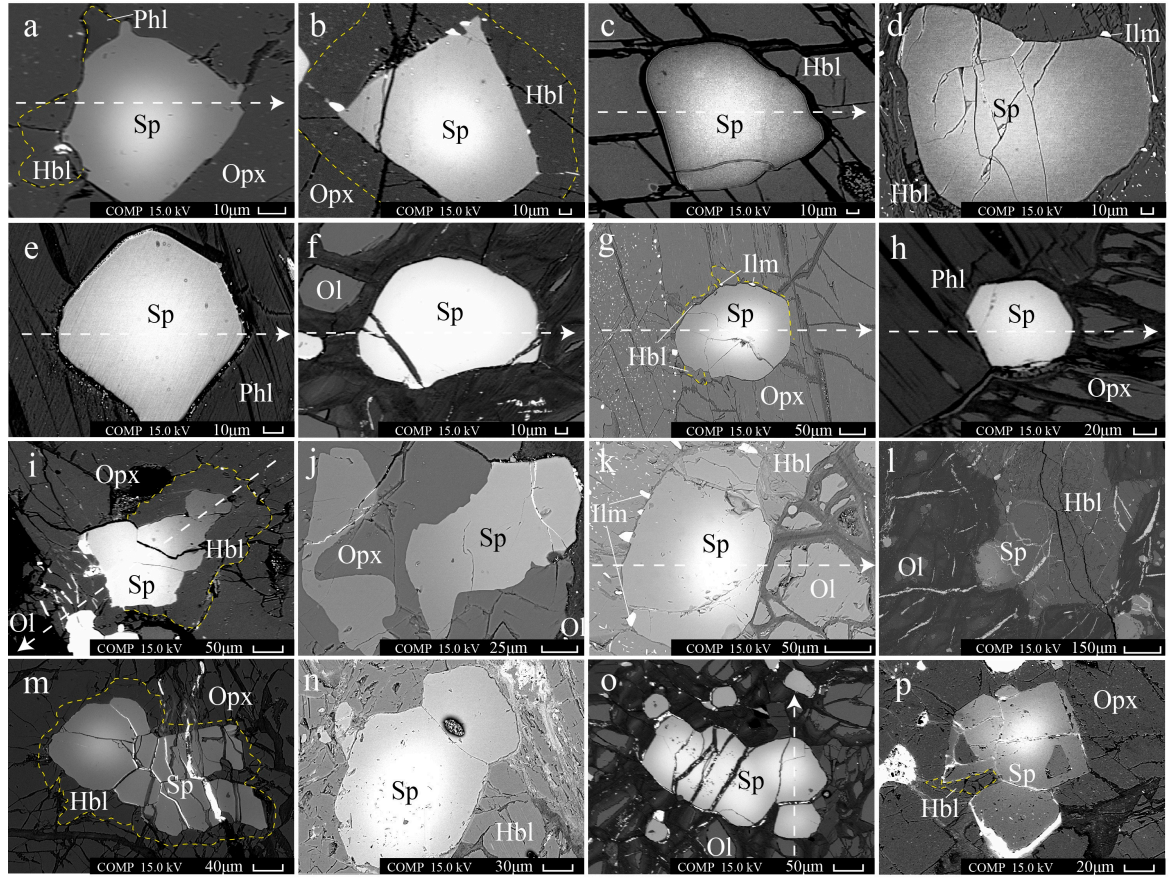

Figure 3. Back-scattered electron images of Cr-spinel (Sp), and the arrows denote the trend of compositional profiles: (a,b) Zoned Cr-spinel surrounded by enstatite (Opx) along with tschermakite $(\mathrm{Hbl})$ and phlogopite (Phl); (c,d) Zoned Cr-spinel surrounded by tschermakite carrying ilmenite (Ilm), showing the seeming disconnection between the reverse zonation and the crack in Cr-spinel; (e) Zoned Cr-spinel surrounded by phlogopite; (f) Zoned Cr-spinel surrounded by olivine; (g) Interstitial zoned Cr-spinel located between tschermakite and enstatite; (h) Interstitial zoned Cr-spinel located between phlogopite and enstatite; $(\mathbf{i}, \mathbf{j})$ Interstitial asymmetrically-zoned $\mathrm{Cr}$-spinel located between olivine and enstatite; (k,1) Interstitial asymmetrically-zoned Cr-spinel located between olivine and tschermakite; $(\mathbf{m}-\mathbf{p}) \mathrm{Cr}$-spinel cluster enclosed in enstatite, tschermakite, and olivine, with only relatively large Cr-spinel grains showing zonation.

The clear distribution of elements in reverse-zoned Cr-spinel and host silicate minerals is evident in elemental mapping images (Figure 4) and representative compositional profile (Figure 5). In general, the Cr-spinel displays a bell-like distribution of the major elements: the cores are enriched in heavy elements such as $\mathrm{Cr}$ and $\mathrm{Fe}$, whereas the rims show conjugated enrichment in light elements such as $\mathrm{Al}$ and $\mathrm{Mg}$. The host silicate minerals are characterized by a general decrease in $\mathrm{Al}$ and $\mathrm{Mg}$ contents accompanied by increasing $\mathrm{Cr}$ and Fe contents with the distances close to $\mathrm{Cr}$-spinel. With respect to the minor elements, the elemental mapping images could hardly detect any non-accidental elemental variation. The limited variation in the contents of $\mathrm{Ni}, \mathrm{Mn}$, and $\mathrm{Ti}$ in both $\mathrm{Cr}$-spinel and host silicate minerals is revealed by the compositional profiles. 

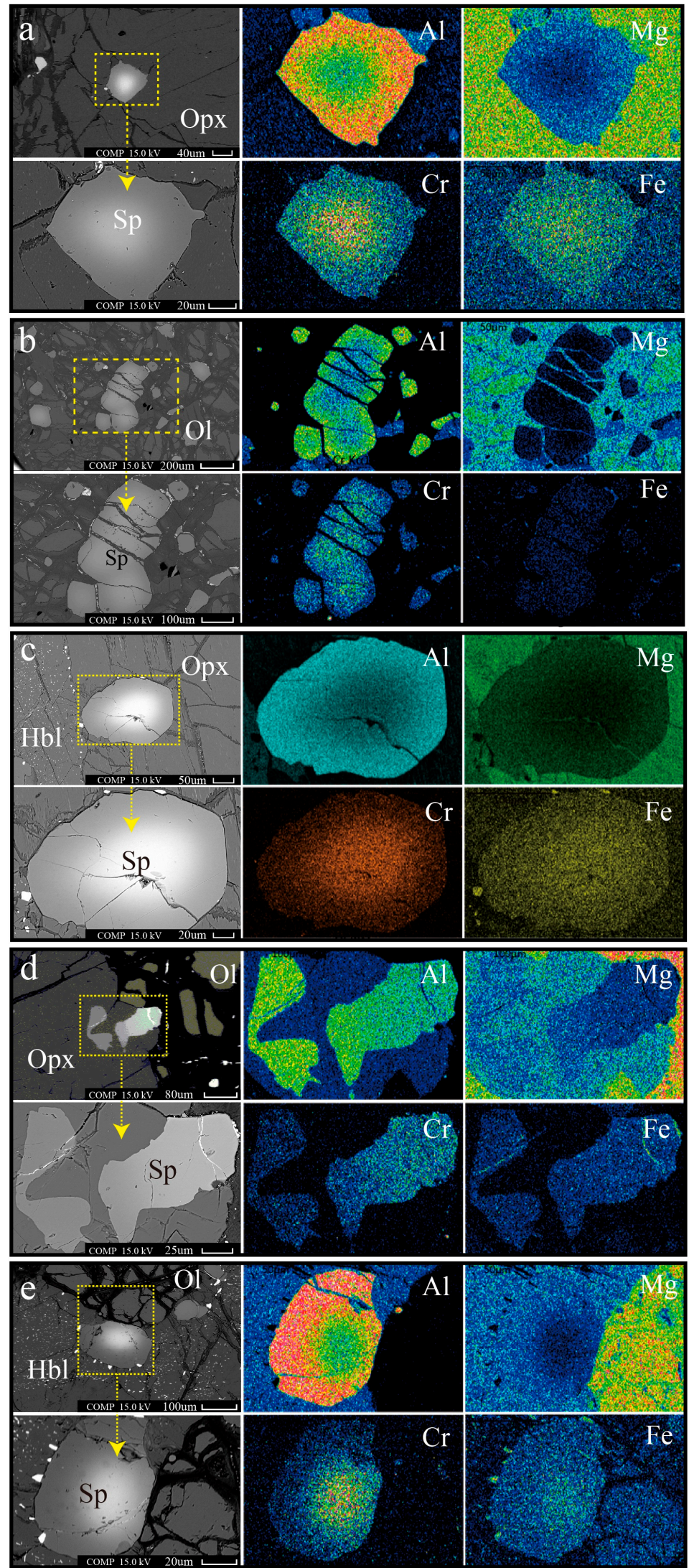

Figure 4. Elemental mapping images of zoned Cr-spinel (Sp): (a) Zoned Cr-spinel surrounded by enstatite (Opx); (b) Cr-spinel cluster enclosed in olivine (Ol); (c) Interstitial zoned Cr-spinel located between tschermakite $(\mathrm{Hbl})$ and enstatite $(\mathrm{Opx})(\mathbf{d})$ Interstitial zoned $\mathrm{Cr}$-spinels located between olivine and enstatite; (e) Interstitial zoned Cr-spinel located between olivine and tschermakite. 

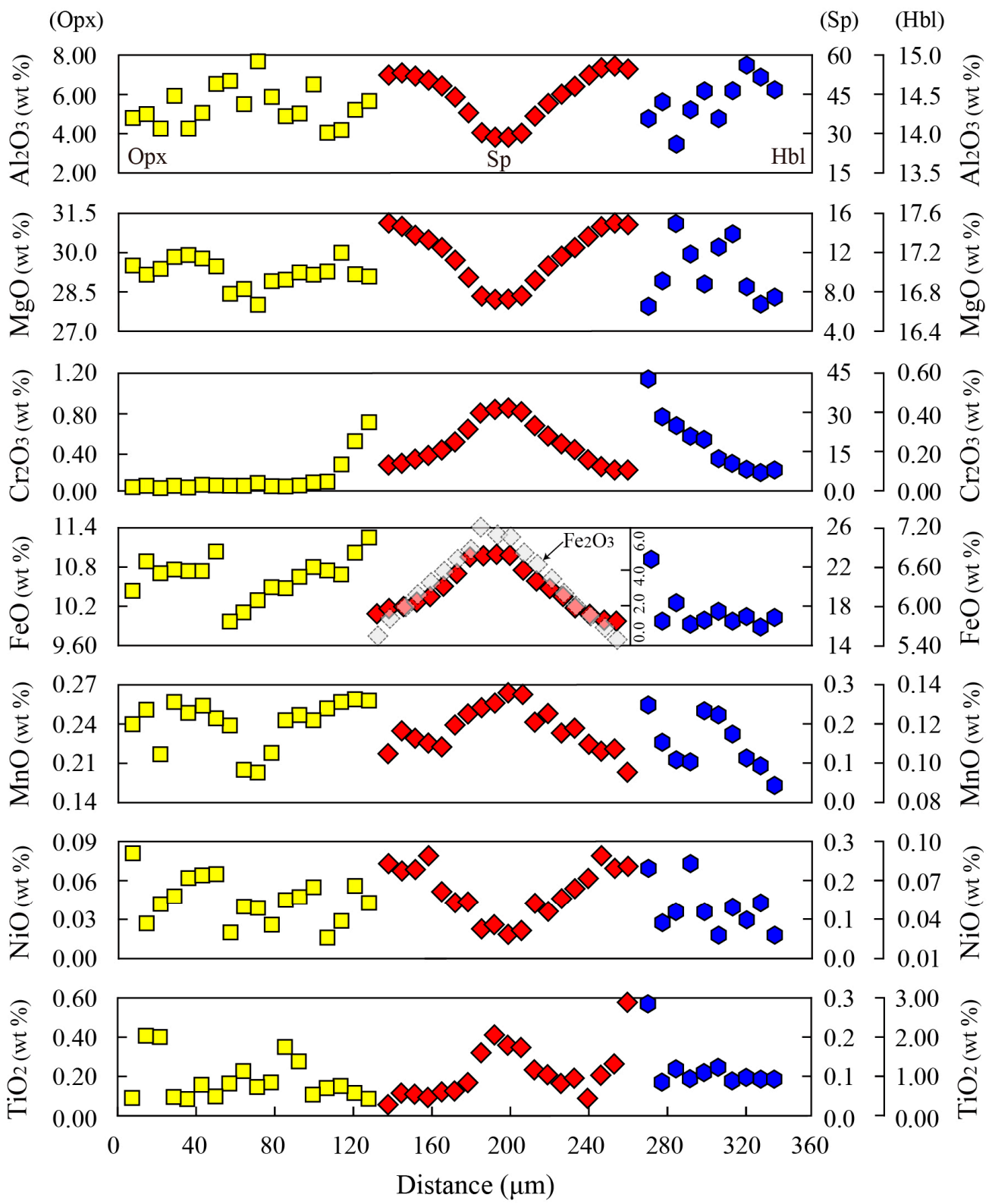

Figure 5. Compositional profile analyses of zoned Cr-spinel located between enstatite and tschermakite. The profile shows in Figure 3k.

\section{Discussion}

Clear reverse zoning in Cr-spinel within the ultramafic rocks of the Yanmenguan complex and the origin(s) of the reverse zonation have been the subject of continuous debate. In this study, therefore, we look at all the possible mechanisms to enable us to establish the most likely process responsible for the observed zonation in the Yanmenguan complex.

\subsection{Reaction with Melt}

\subsubsection{Reaction with Non-Homologous Melt}

The reaction between crystals and non-homologous melt may generate reverse zoning in spinels $[34,35,47]$. The most common is the inherited or captured spinel grains, exhibiting sharp variation from $\mathrm{Cr}$-rich core to Al-rich rim. This kind of reverse zoning has been reported in arc volcanic rocks [48] and those in greenstone belts [49], suggesting marked disequilibrium between spinel core 
and host silicate liquid. However, the limited number of inherited spinel is inconsistent with the abundance of zoned spinel in the Yanmenguan complex.

Magma mixing or assimilation with crust-derived wall rock can also result in significant change in the melt composition as well as the disequilibrium between the previously formed core and the evolved silicate liquid. Relevant studies have been reported in seamount lavas [35] and tholeiitic basaltic magmas [36]. This mechanism can explain the localized asymmetric zonation in Cr-spinel hosted in olivine and shielded from reaction with mixed magma (Figure 3i-l). However, the evolved melt can be excluded by the contradiction of increasing $\mathrm{Cr}$ concentrations in silicates and increasing $\mathrm{Al}$ concentrations in spinel (Figure 5). Thus, the reaction with non-homologous melt could not be the fundamental cause of the reverse zonation observed in the Cr-spinel from the Yanmenguan complex.

\subsubsection{Reaction with Homologous Melt}

It has been suggested that abundant [34] or rapid [21,28] growth of spinels could lead to localized Cr-depletion in homologous melt, and the continued growth of accumulated spinel grains gives rise to the massive reverse zoning texture in the postcumulus stage. The former is well-documented in the large, layered mafic-ultramafic complex, in which the extensive accumulation of chromitite as well as the absence of supplementary magma could also induce the dramatic change in melt composition and generate reverse zoning chromite (Rhum-layered mafic-ultramafic complex [33]; Panton Sill-layered mafic-ultramafic complex [34]). However, it is clearly different from the sparse Cr-spinel in the Yanmenguan complex, which can hardly lead to the large-scale variation in the melt at the post cumulus stage.

The latter is currently the dominant origin for reverse zoning spinels which, combined with the relative difficulty of nucleating crystals of Al-rich silicate minerals $[20,29,47,50]$, results in the formation of extremely Al-rich melt. The increasing $\mathrm{Al}$ with decreasing $\mathrm{Cr}$ could result in progressive changes in crystal chemistry of the spinels from $\mathrm{Cr}$ - and Fe-rich crystal cores to Al- and Mg-rich rims and leading to the formation of reverse zonation [28,30,51-54]. Related observation was first described by Sigurdsson [25] to explain the intensely-zoned spinels in olivine-spinel pairs in basalts collected during the ocean drilling program, marked by a decrease in $\mathrm{Cr} \#(\mathrm{Cr} /(\mathrm{Cr}+\mathrm{Al}) \times 100)$ from core to rim with re-equilibrated zoning of $\mathrm{Mg} \#\left(\mathrm{Mg} /\left(\mathrm{Mg}+\mathrm{Fe}^{2+}\right) \times 100\right)$ [55]. Subsequently, the reverse-zoned spinel grains through the same mechanism have been reported in alkali basaltic glasses from Iceland [21,31], quenched basaltic lavas from Hawaii [56], and MORB-type greenstones in East Takayama [32], and confirmed by thermodynamic experiments [26].

This mechanism is well-documented to explain the gradual elemental change in spinel core and rim by continuous crystallization (e.g., Figure $3 a$ ) and the larger crystals display more distinct zoning texture than the small ones (Figure $3 \mathrm{~m}-\mathrm{p}$ ) caused by the different nucleation period $[33,34,50]$. The asymmetric zonation (Figure 3i-l) most likely resulted from local melt heterogeneity due to disequilibrium induced by crystallization of various phases with different compositions, which could affect the diffusion rates of ions into the growing crystals [33,50,57]. However, this type of reverse zonation is usually generated in the olivine-spinel paired samples, accompanied by the absence of Al-rich silicate minerals [50,57]. On the contrary, zoned Cr-spinel grains are preferentially distributed in the enstatite (Figure 3a,b), tschermakite (Figure 3c,d), and phlogopite (Figure 3e) in the Yanmenguan complex, where the abundant silicate minerals could buffer the $\mathrm{Cr} / \mathrm{Al}$ ratio in melt to some extent [32]. More importantly, the compositional variation in spinel from core to rim cannot decrease temperature and increase oxygen fugacity (Figure 6a), suggesting that the zonation could not be the result of fractional crystallization [58]. In addition, the marked increase in $\mathrm{Cr}$ and decrease in $\mathrm{Al}$ in silicate minerals cannot conform to the elemental variation of magma differentiation (Figure 5). Therefore, the aforementioned mechanisms could not explain the reverse zonation in the Yanmenguan complex. 

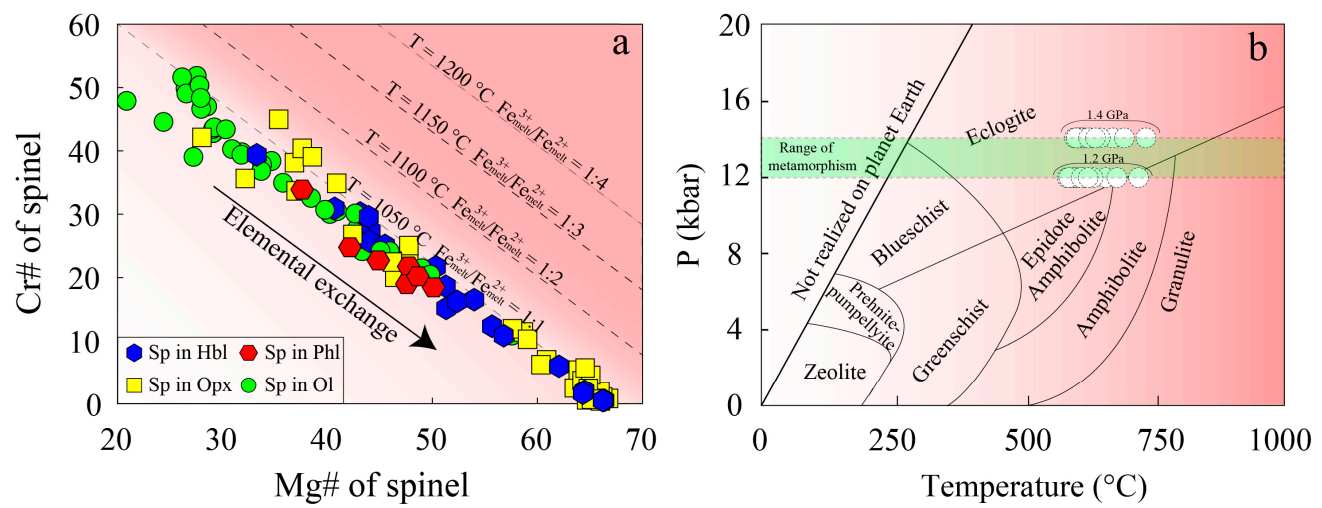

Figure 6. (a) Cr-spinel empirical thermometer after Sack and Ghiorso [58]. The equipotential curves and $\mathrm{Fe}^{3+} / \mathrm{Fe}^{2+}$ of melt are from Irvine [1] and Agata and Adachi [33]. Equipotential curves shifting to the left represent magmatic differentiation, and the paralleled arrow denotes the trend of elemental exchange. (b) Olivine-spinel thermometer after Ballhaus [59]. The compositions for temperature estimates based on the rim of spinel and co-existing olivine. The presupposed pressures (1.2 and $1.4 \mathrm{GPa}$ ) are from Wang et al. [39]. Data are available in supplementary material. P-T diagram with eight principal metamorphic facies is from Spear [60].

\subsection{Elemental Exchange with Coexisting Silicate Minerals}

Elemental exchange with coexisting silicate minerals is another important factor modifying the composition of spinel [61-65], and is commonly induced by the variation of physical conditions [66-69]. Generally, diffusion-induced zonation is caused by the long-term exchange between crystals subjected to continuous, high subsolidus temperatures [23,70-72]. In the study of the Red Mountain Alpine-type mafic-ultramafic complex in South Island, New Zealand [22,72-74], Sinton [22] discovered significant reverse zoning in spinel grains in a spinel-enstatite pair. It is believed that the continuous reaction with enstatite led to the enrichment of $\mathrm{Al}$ and $\mathrm{Mg}$ in the Cr-spinel, whereas the enstatite became enriched in $\mathrm{Cr}$ and $\mathrm{Fe}$. Similar interpretations were assigned to reverse zonation in spinel grains from the Rhum-layered mafic-ultramafic complex in Scotland [37] and also to spinel grains from the Gabbro Akarem Alaskan-type mafic-ultramafic complex in Egypt [24,75,76].

The aforementioned compositional variations between spinel and silicate minerals are consistent with the result of elemental mapping images (Figure 4) and compositional profiles (Figure 5) of the Yanmenguan complex. The asymmetrical zonation (Figure 3i-k) is interpreted to be caused by various degrees of elemental exchange with different silicate minerals, which are also characterized by variable degrees of solubility and different capacities to accommodate elements [22,77-79]. Thus, tschermakite, phlogopite, and enstatite with higher contents of $\mathrm{Al}$ and high $\mathrm{Cr}$-bearing capacity impose greater influence on spinel than olivine, which only contains limited concentrations of $\mathrm{Cr}[72,80,81]$ and $\mathrm{Al}[82,83])$, and acts as a relatively perfect barrier to elemental diffusion [84]. In addition, the characteristic of large Cr-spinel grains preserving well-developed zonation (Figure $3 \mathrm{~m}-\mathrm{p}$ ) suggests that the relatively small grains are completely controlled or equilibrated by the surrounding silicate minerals, thereby destroying the zoned texture [85]. Obviously, the elemental exchange with coexisting silicate minerals can reasonably explain the reverse zonation in Cr-spinel.

\subsection{Inducement of Elemental Exchange}

According to the empirical model supplied by Sack and Ghiorso [58], the crystallization temperature of the $\mathrm{Cr}$-spinel in the Yanmenguan complex approximates $1050{ }^{\circ} \mathrm{C}$ (Figure 6a). However, the calculated temperature of the spinel-olivine pair from the Yanmenguan complex measured by the thermodynamics thermometer from Ballhaus [59] yielded a range of $600-720^{\circ} \mathrm{C}$, which is similar to the medium- and high-grade metamorphic temperature (Figure $6 \mathrm{~b}$ ). The calculated temperature may be associated with the complex metamorphic history recorded in the Hengshan-Wutai-Fuping area. 
Previous studies have shown that a pre-existing ocean was completely consumed by subduction between the Eastern and Western Blocks of the North China Craton [38,86,87]. Consequently, the continent-arc-continent collision [88] introduced those rocks into lower crustal levels or the upper mantle [88], where granulite to eclogite facies [89-92] or greenschist to lower amphibolite facies [93-96] metamorphism occurred. This metamorphic history may provide long-lived dynamics and thermal status for elemental exchange in the Yanmenguan complex.

In fact, the occurrence of the coexistence of both reddish-brown and green spinel grains in the Nikubuchi peridotite in Japan has been reported [97]. The textural relationships and mineral chemistry of the Nikubuchi rocks indicate that the spinel from the peridotite was equilibrated at granulite facies conditions before being emplaced into the Sanbagawa metamorphic belt [97]. Similar occurrences are also recorded in ultramafic peridotite rocks metamorphosed under granulite facies conditions from the Rio de Las Tunas Belt in Argentina [98]. In Skye Island, the peridotite is also characterized by the occurrence of red and green spinel grains. Lenaz et al. [99] suggested that the green pleonaste is a by-product of the metasomatism of previously $\mathrm{Cr}$-rich spinel, resulting in the mobilization of $\mathrm{Cr}$ during a localized thermal event.

Interestingly, the elemental exchange is commonly mentioned in $\mathrm{Mg}-\mathrm{Fe}^{2+}$ exchange without the equilibrium of $\mathrm{Cr}-\mathrm{Al}-\mathrm{Fe}^{3+}$, because the diffusion rates of divalent ions are several magnitudes faster than those of trivalent ions [24]. However, all the compositional profiles in this study show that elemental exchange is more pronounced in $\mathrm{Cr}-\mathrm{Al}-\mathrm{Fe}^{3+}$ than in $\mathrm{Mg}-\mathrm{Fe}^{2+}$ (Figure 5 and Supplementary Materials). We assume the discrepancy could be associated with the relatively faster rate of diffusion of divalent ions in Cr-spinel, during which the well-developed zonation preferentially preserves trivalent ions instead of divalent ions. The blocking temperatures of divalent ions are also lower than those of trivalent ions [23], and therefore, the increased frequency and prolonged exchange of divalent ions between the core and rim of Cr-spinel can destroy the already formed zonation texture. It is suggested that the re-equilibration of spinel with adjacent silicate restricts the application of spinel to investigate igneous processes $[15,23,100,101]$. Thus, the trivalent ions may be relatively appropriate, especially for olivine-hosted spinel (Figure 6a), to trace the original composition of spinel (Figure 7a,b). There are limited variations in the contents of $\mathrm{Ni}, \mathrm{Mn}$, and $\mathrm{Ti}$ in $\mathrm{Cr}$-spinel (Figure 5). In this respect, much attention should be paid to these minor elements in their application to trace geologic processes (Figure 7c), since these elements are not affected by elemental exchange and are therefore more reliable and valid than the traditional index [64].
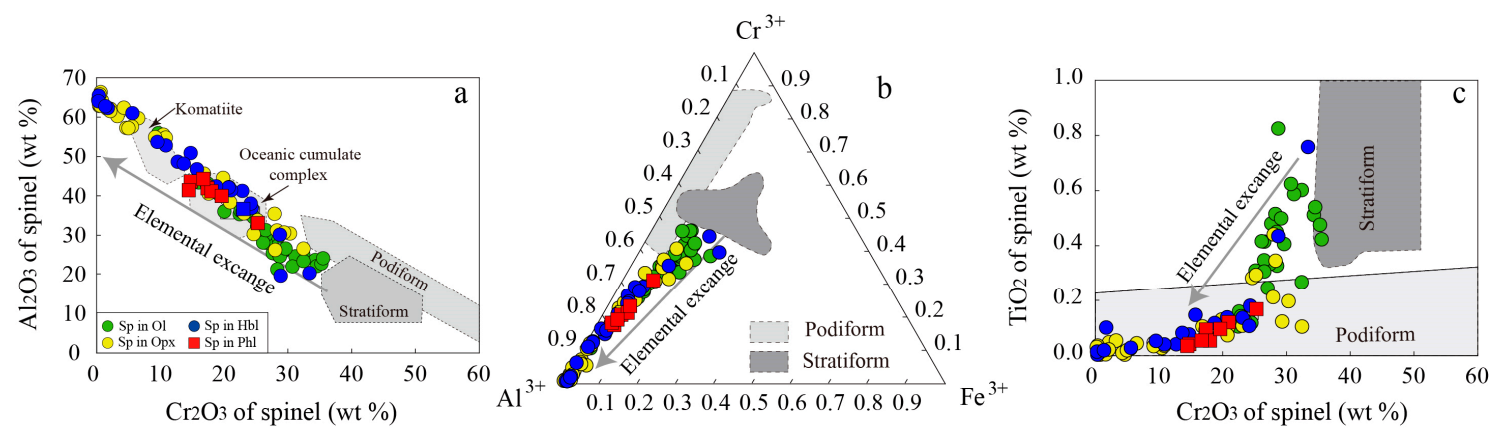

Figure 7. Chemical compositions of spinel, compared with spinel from different tectonic settings on (a) $\mathrm{Cr}_{2} \mathrm{O}_{3}$ vs. $\mathrm{Al}_{2} \mathrm{O}_{3}$ (b) $\mathrm{Cr}_{2} \mathrm{O}_{3}$ vs. $\mathrm{Al}_{2} \mathrm{O}_{3}$ vs. $\mathrm{Fe}_{2} \mathrm{O}_{3}$ (c) $\mathrm{TiO}_{2}$ vs. $\mathrm{Cr}_{2} \mathrm{O}_{3}$ diagrams. The komatiite and oceanic cumulate complex fields are from Kamenetsky et al. [5]. Podiform and stratiform fields are from Musallam et al. [102] and Arai et al. [103].

\section{Conclusions}

The widespread reverse zoning in Cr-spinel from rocks of the Yanmenguan complex is compositionally characterized by $\mathrm{Al}$ - and $\mathrm{Mg}$-rich rims and $\mathrm{Cr}$ - and Fe-rich cores. The zoning 
texture is discriminative in the different host silicate minerals and the sizes of Cr-spinel grains. These features rule out fractional crystallization and the reaction with melt as responsible for the zoning. The compositional profiles traversing the $\mathrm{Cr}$-spinel and host silicate mineral were generated to investigate the elemental exchange reaction that gave rise to the zonation. Based on the calculated temperature of $600-720^{\circ} \mathrm{C}$, we postulate that the metamorphic event was the origin of elemental exchange in the Hengshan-Wutai-Fuping area.

Supplementary Materials: The following are available online at http:/ /www.mdpi.com/2075-163X/8/2/62/s1, Figure S1: Compositional profiles of reverse zoned spinel in enstatite; Figure S2: Compositional profiles of reverse zoned spinel in tschermakite; Figure S3: Compositional profiles of reverse zoned spinel in phlogopite; Figure S4: Compositional profiles of reverse zoned spinel in olivine; Figure S5: Compositional profiles of zoned spinel among enstatite and olivine; Figure S6: Compositional profiles of zoned spinel among enstatite and phlogopite; Figure S7: Compositional profiles of zoned spinel among olivine and phlogopite; Table S1: Data of compositional profiles; Table S2: Supplementary coupled olivine and spinel compositions for temperature estimations.

Acknowledgments: This study was financially supported by the National Key R\&D Program of China (Grant No. 2017YFC0601306), the National Natural Science Foundation of China (Grant No. 41522203), and Youth Innovation Promotion Association, Chinese Academy of Sciences (Grant No. 2016067).

Author Contributions: Yang Bai, Ben-Xun Su, Yan Xiao, Zi liang and Chen Chen collected the samples and data; Ben-Xun Su and Yan Xiao conceived and designed the experiments; Yang Bai and Sai-Hong Yang performed the experiments; Zi Liang analyzed the data and prepared the draft with Chen Chen. Davide Lenaz, Patrick Asamoah Sakyi and Ben-Xun Su revised the paper and provided some contributions to the data interpretation, and funding for this work.

Conflicts of Interest: The authors declare no conflict of interest.

\section{References}

1. Irvine, T.N. Chromian spinel as a petrogenetic indicator: Part I. Theory. Can. J. Earth Sci. 1965, 2, 648-672. [CrossRef]

2. Irvine, T.N. Chromian spinel as a petrogenetic indicator: Part II. Petrologic applications. Can. J. Earth Sci. 1967, 4, 71-103. [CrossRef]

3. Dick, H.J.B.; Bullen, T. Chromian spinel as a petrogenetic indicator in abyssal and Alpine-type peridotites and spatially associated lavas. Contrib. Mineral. Petrol. 1984, 86, 54-76. [CrossRef]

4. Barnes, S.J.; Roeder, P.L. The range of spinel compositions in terrestrial mafic and ultramafic rocks. J. Petrol. 2001, 42, 2279-2302. [CrossRef]

5. Kamenetsky, V.S.; Crawford, A.J.; Meffre, S. Factors controlling chemistry of magmatic spinel: An empirical study of associated olivine, Cr-spinel and melt inclusions from primitive rocks. J. Petrol. 2001, 42, 655-671. [CrossRef]

6. Pagé, P.; Barnes, S.J. Using trace elements in chromites to constrain the origin of podiform chromitites in the Thetford Mines ophiolite, Québec, Canada. Econ. Geol. 2009, 104, 997-1018. [CrossRef]

7. Abzalov, M.Z. Chrome-spinels in gabbro-wehrlite intrusions of the Pechenga area, Kola Peninsula, Russia: Emphasis on alteration features. Lithos 1998, 43, 109-134. [CrossRef]

8. Merlini, A.; Grieco, G.; Diella, V. Ferritchromite and chromian-chlorite formation in mélange-hosted Kalkan chromitite (Southern Urals, Russia). Am. Mineral. 2009, 94, 1459-1467. [CrossRef]

9. Aswad, K.J.; Aziz, N.R.; Koyi, H.A. Cr-spinel compositions in serpentinites and their implications for the petrotectonic history of the Zagros suture zone, Kurdistan region, Iraq. Geol. Mag. 2011, 148, 802-818. [CrossRef]

10. Ahmed, A.H.; Surour, A.A. Fluid-related modifications of Cr-spinel and olivine from ophiolitic peridotites by contact metamorphism of granitic intrusions in the Ablah area, Saudi Arabia. J. Asian Earth Sci. 2016, 122, 58-79. [CrossRef]

11. Evans, B.W.; Frost, B.R. Chrome-spinel in progressive metamorphism-a preliminary analysis. Geochim. Cosmochim. Acta 1975, 39, 959-972. [CrossRef]

12. Barnes, S.J. Chromite in komatiites, II. Modification during greenschist to mid-amphibolite facies metamorphism. J. Petrol. 2000, 41, 387. [CrossRef] 
13. Su, B.X.; Zhang, H.F.; Sakyi, P.A.; Yang, Y.H.; Ying, J.F.; Tang, Y.J.; Qin, K.Z.; Xiao, Y.; Zhao, X.M.; Mao, Q.; et al. The origin of spongy texture in minerals of mantle xenoliths from the Western Qinling, central China. Contrib. Mineral. Petrol. 2011, 161, 465-482. [CrossRef]

14. Hu, S.L.; Luo, D.; Chen, L.H. Genesis of sieve-textured rim of spinel in mantle xenoliths. Acta Petrol. Sin. 2017, 33, 69-80.

15. Colás, V.; González-Jiménez, J.M.; Griffin, W.L.; Fanlo, I.; Gervilla, F.; O’Reilly, S.Y. Fingerprints of metamorphism in chromite: New insights from minor and trace elements. Chem. Geol. 2014, 389, 137-152. [CrossRef]

16. Gervilla, F.; Padrón-Navarta, J.; Kerestedjian, T.; Sergeeva, I.; González-Jiménez, J.; Fanlo, I. Formation of ferrian chromite in podiform chromitites from the Golyamo Kamenyane serpentinite, Eastern Rhodopes, SE Bulgaria: A two-stage process. Contrib. Mineral. Petrol. 2012, 164, 1-15. [CrossRef]

17. Mukherjee, R.; Mondal, S.K.; Rosing, M.T.; Frei, R. Compositional variations in the Mesoarchean chromites of the Nuggihalli schist belt, western Dharwar Craton (India): Potential parental melts and implications for tectonic setting. Contrib. Mineral. Petrol. 2010, 160, 865-885. [CrossRef]

18. O'Hanley, D.S.; Chernosky, J.V.; Wicks, F.J. The stability of lizardite and chrysotile. Can. Mineral. 1989, 27, 483-493.

19. Barra, F.; Gervilla, F.; Hernández, E.; Reich, M.; Padrón-Navarta, J.A.; González-Jiménez, J.M. Alteration patterns of chromian spinels from La Cabaña peridotite, south-central Chile. Mineral. Petrol. 2014, 108, 819-836. [CrossRef]

20. El Goresy, A.; Prinz, M.; Ramdohr, P. Zoning in spinels as an indicator of the crystallization histories of mare basalts. In Proceedings of the 7th Lunar Science Conference, Houston, TX, USA, 15-19 March 1976; Volume 7, pp. 1261-1279.

21. Thy, P. Spinel minerals in transitional and alkali basaltic glasses from Iceland. Contrib. Mineral. Petrol. 1983, 83, 141-149. [CrossRef]

22. Sinton, J.M. Equilibration history of the Basel alpine-type peridotite, Red Mountain, New Zealand. J. Petrol. 1977, 18, 216-246. [CrossRef]

23. Yang, K.; Seccombe, P.K. Chemical variation of chromite in the ultramafic cumulates of the Great Serpentinite Belt, Upper Bingara to Doonba, New South Wales, Australia. Can. Mineral. 1993, 31, 75-87.

24. Ahmed, A.H.; Helmy, H.M.; Arai, S.; Yoshikawa, M. Magmatic unmixing in spinel from late Precambrian concentrically-zoned mafic-ultramafic intrusions, eastern desert, Egypt. Lithos 2008, 104, 85-98. [CrossRef]

25. Sigurdsson, H. Spinels in Leg 37 basalts and peridotites: Phase chemistry and zoning. In Initial Reports of the Deep Sea Drilling Project; Aumento, F., Melson, W.G., Hall, J.M., Eds.; Texas A\&M University: College Station, TX, USA, 1977; Volume 37, pp. 883-891.

26. Fisk, M.R.; Bence, A.E. Experimental crystallization of chrome spinel in Famous Basalt 527-1-1. Earth Planet. Sci. Lett. 1980, 48, 111-123. [CrossRef]

27. Liermann, H.P.; Ganguly, J. Diffusion kinetics of $\mathrm{Fe}^{2+}$ and $\mathrm{Mg}$ in aluminous spinel: Experimental determination and applications. Geochim. Cosmochim. Acta 2002, 66, 2903-2913. [CrossRef]

28. Allan, J.F.; Sack, R.O.; Batiza, R. Cr-rich spinels as petrogenetic indicators; MORB-type lavas from the Lamont seamount chain, eastern Pacific. Am. Mineral. 1988, 43, 6-16.

29. Longhi, J. Experimental petrology and petrogenesis of mare volcanics. Geochim. Cosmochim. Acta 1992, 56, 2235-2251. [CrossRef]

30. Longhi, J.; Fram, M.S.; Auwera, J.V.; Montieth, J.N. Pressure effects, kinetics, and rheology of anorthositic and related magmas. Am. Mineral. 1993, 78, 1016-1030.

31. Roeder, P.L.; Poustovetov, A.; Oskarsson, N. Growth forms and composition of chromian spinel in MORB magma: Diffusion-controlled crystallization of chromian spinel. Can. Mineral. 2001, 39, 397-416. [CrossRef]

32. Agata, T.; Adachi, M. Chrome spinel in normal MORB-type greenstones from the Paleozoic-Mesozoic Mino Terrane, east Takayama area, central Japan: Crystallization course with a U-turn. Island Arc 2014, 23, 62-73. [CrossRef]

33. Henderson, P.; Suddaby, P. The nature and origin of the chrome-spinel of the Rhum layered intrusion. Contrib. Mineral. Petrol. 1971, 33, 21-31. [CrossRef]

34. Hamlyn, P.R.; Keays, R.R. Origin of chromite compositional variation in the Panton Sill, western Australtalia. Contrib. Mineral. Petrol. 1979, 69, 75-82. [CrossRef]

35. Allan, J.F.; Batiza, R.; Perfit, M.R.; Fornari, D.J.; Sack, R.O. Petrology of lavas from the Lamont seamount chain and adjacent east Pacific rise, $10^{\circ}$ N. J. Petrol. 1989, 30, 1245-1298. [CrossRef] 
36. Peltonen, P. Crystallization and re-equilibration of zoned chromite in ultramafic cumulates, Vammala Ni-Belt, Southwestern Finland. Can. Mineral. 1995, 33, 521-535.

37. Henderson, P.; Wood, R.J. Reaction relationships of chrome-spinels in igneous rocks-further evidence from the layered intrusion of Rhum and Mull, Inner Hebrides, Scotland. Contrib. Mineral. Petrol. 1981, 78, 225-229. [CrossRef]

38. Zhao, G.C.; Liu, S.W.; Sun, M.; Li, S.Z.; Wilde, S.; Xia, X.P.; Zhang, J.; He, Y.H. What happened in the Trans-North China Orogen in the period 2560-1850 Ma? Acta Geol. Sin. 2006, 80, 790-806. [CrossRef]

39. Wang, K.Y.; Li, J.L.; Hao, J.; Chai, Y.C.; Zhou, S.P. Late Archean mafic-ultramafic rocks from the Wutaishan, Shanxi Province: A possible ophiolite melange. Acta Petrol. Sin. 1997, 13, 139-151.

40. Li, J.L.; Wang, K.Y.; Wang, Q.C.; Liu, X.H.; Zhao, Z.Y. Early Proterozoic collision orogenic belt in Wutaishan area China. Sci. Geol. Sin. 1990, 25, 1-11.

41. Bai, J.; Wang, R.Z.; Guo, J.J. The Major Geological Events of Early Precambrian and Their Age Dating in the Wutai Region; Geological Publishing House: Beijing, China, 1992; pp. 1-52.

42. Polat, A.; Kusky, T.M.; Li, J.H.; Fryer, B.; Kerrich, R.; Patrick, K. Geochemistry of Neoarchean (ca. 2.55-2.50 $\mathrm{Ga}$ ) volcanic and ophiolitic rocks in the Wutaishan greenstone belt, central orogenic belt, North China Craton: Implications for geodynamic setting and continental growth. Geol. Soc. Am. Bull. 2005, 117, 1387-1399. [CrossRef]

43. Wang, Z.H.; Wilde, S.A.; Wan, J. Tectonic setting and significance of 2.3-2.1 Ga magmatic events in the trans-north China orogen: New constraints from the Yanmenguan mafic-ultramafic intrusion in the Hengshan-Wutai-Fuping area. Precambrian Res. 2010, 178, 27-42. [CrossRef]

44. Droop, G.T.R. A general equation for estimating $\mathrm{Fe}^{3+}$ concentrations in ferromagnesian silicates and oxides from microprobe analyses, using Stoichiometric Criteria. Mineral. Mag. 1987, 51, 431-435. [CrossRef]

45. Wan, J.L.; Wang, Z.H. Geochemistry, petrogenesis and tectonic setting of the Paleoproterozoic Yanmenguan mafic-ultramafic intrusion in the Hengshan-Wutai-Fuping area. Acta Petrol. Sin. 2012, 28, 2629-2646.

46. Wendt, A.S.; Altenberger, U.; D'Arco, P. Radiating cracks around chromite inclusions in olivine: Constraints on P-T histories based on the thermoelastic properties of minerals. Schweiz. Mineral. Geosci. Suppl. 1998, 78, 365-374.

47. Roeder, P.L.; Reynolds, I. Crystallization of chromite and chromium solubility in basaltic melts. J. Petrol. 1991, 32, 909-934. [CrossRef]

48. Forsythe, L.M.; Fisk, M.R. Comparison of experimentally crystallized and natural spinels from Leg 135. In Proceedings of the Ocean Drilling Program; Hawkins, J., Parson, L., Allan, J., Eds.; Scientific Results; Texas A\&M University: College Station, TX, USA, 1994; Volume 135, pp. 585-594.

49. Agata, T.; Hattori, I. Chromite in greenstone lavas from the Kanakasu area, Nanjo Massif of the Mesozoic Mino terrane, central Japan. Mineral. Mag. 2002, 66, 575-590. [CrossRef]

50. Henderson, P. Reaction trends shown by chrome-spinels of the Rhum layered intrusion. Geochim. Cosmochim. Acta 1975, 39, 1035-1044. [CrossRef]

51. Sekerka, R.F. Role of instabilities in determination of the shapes of growing crystals. J. Cryst. Growth 1993, 128, 1-12. [CrossRef]

52. Roeder, P.L.; Emslie, R.F. Olivine-liquid equilibrium. Contrib. Mineral. Petrol. 1970, 29, 275-289. [CrossRef]

53. Himmerberg, G.R.; Loney, R.A. Petrology of ultramafic and gabbroic rocks of the Canyon mountain ophiolite, Oregon. Am. J. Sci. 1980, 280, 232-268.

54. Agata, T. Chrome spinels from the Oura layered igneous complex, central Japan. Lithos 1988, 21, 97-108. [CrossRef]

55. Ozawa, K. Relationships between tectonite and cumulate in ophiolites: The Miyamori ultramafic complex, Kitakami mountains, northeast Japan. Lithos 1983, 16, 1-16. [CrossRef]

56. Roeder, P.; Gofton, E.; Thornber, C. Cotectic proportions of olivine and spinel in olivine-tholeiitic basalt and evaluation of pre-eruptive processes. J. Petrol. 2005, 47, 883-900. [CrossRef]

57. Cameron, E.N. Postcumulus and subsolidus equilibration of chromite and coexisting silicates in the eastern Bushveld Complex. Geochim. Cosmochim. Acta 1975, 39, 1021-1033. [CrossRef]

58. Sack, R.O.; Ghiorso, M.S. Chromite as a petrogenetic indicator. Rev. Mineral. Geochem. 1991, 25, $323-353$.

59. Ballhaus, C. Redox states of lithospheric and asthenospheric upper mantle. Contrib. Mineral. Petrol. 1993, 114, 331-348. [CrossRef]

60. Spear, F.S. Metamorphic phase equilibria and pressure-temperature-time paths. Mineral. Soc. Am. 1995, 1, 172-174. 
61. Jackson, E.D. Chemical Variation in coexisting chromite and olivine in chromite zones of the Stillwater complex. Econ. Geol. Monogr. 1969, 4, 41-47.

62. Wilson, A.H. The geology of the Great "Dyke", Zimbabwe: The ultramafic rocks. J. Petrol. 1982, $23,240-292$. [CrossRef]

63. Hatton, C.J.; von Gruenewaldt, G. Chromite from the Swartkop chrome mine-an estimate of the effects of subsolidus re-equilibration. Econ. Geol. 1985, 80, 911-924. [CrossRef]

64. Xiao, Y.; Teng, F.Z.; Su, B.X.; Hu, Y.; Zhou, M.F.; Zhu, B.; Shi, R.D.; Huang, Q.S.; Gong, X.H.; He, Y.S. Iron and magnesium isotopic constraints on the origin of chemical heterogeneity in podiform chromitite from the Luobusa ophiolite, Tibet. Geochem. Geophys. Geosyst. 2016, 17, 940-953. [CrossRef]

65. Bai, Y.; Su, B.X.; Chen, C.; Yang, S.H.; Liang, Z.; Xiao, Y.; Qin, K.Z.; Malaviarachchi, S.P.K. Base metal mineral segregation and $\mathrm{Fe}-\mathrm{Mg}$ exchange inducing extreme compositions of olivine and chromite from the Xiadong Alaskan-type complex in the southern part of the Central Asian Orogenic Belt. Ore Geol. Rev. 2017, 90, 184-192. [CrossRef]

66. Dickey, J.S.; Yoder, H.S. Partitioning of chromium and aluminium between clinopyroxene and spinel. Carnegie Inst. Wash. Yearb. 1972, 71, 384-392.

67. Green, D.H.; Ringwood, A.E.; Ware, N.G.; Hibberson, W.O. Experimental petrology and petrogenesis of Apollo 14 basalts. Lunar Planet. Sci. Conf. Proc. 1972, 3, 197.

68. Herzberg, C.T.; Chapman, N.A. Clinopyroxene geothermometry of spinel-lherzolites. Am. Mineral. 1976, 61, 7-8.

69. Fujii, T. Fe-Mg partitioning between olivine and spinel. Carnegie Inst. Wash. Yearb. 1977, 75, 566-571.

70. Buening, D.K.; Buseck, P.R. Fe-Mg lattice diffusion in olivine. J. Geophys. Res. 1973, 78, 6852-6862. [CrossRef]

71. Freer, R.; O'Reilly, W. The diffusion coefficient of $\mathrm{Fe}^{3+}$ ions in spinels with relevance to the process of maghemitization. Mineral. Mag. 1980, 43, 889-899. [CrossRef]

72. Lehmann, J. Diffusion between olivine and spinel: Application to geothermometry. Earth Planet. Sci. Lett. 1983, 64, 123-138. [CrossRef]

73. Sinton, J.M. Structure, Petrology and Metamorphism of the Red Mountain Ophiolite Complex, New Zealand. Ph.D. Thesis, University of Otago, Dunedin, New Zealand, 1975.

74. Dick, H.J.B.; Sinton, J.M. Compositional layering in alpine peridotites: Evidence for pressure solution creep in the mantle. J. Geol. 1979, 87, 403-416. [CrossRef]

75. Helmy, H.M.; El Mahallawi, M.M. Gabbro Akarem mafic-ultramafic complex, Eastern Desert, Egypt: A Late Precambrian analogue of Alaskan-type complexes. Mineral. Petrol. 2003, 77, 85-108. [CrossRef]

76. Farahat, E.S.; Helmy, H.M. Abu Hamamid Neoproterozoic Alaskan-type complex, south Eastern Desert, Egypt: Petrogenetic and geotectonic implications. J. Afr. Earth Sci. 2006, 85, 187-197. [CrossRef]

77. Ozawa, K. Olivine-spinel geospeedometry: Analysis of diffusion-controlled $\mathrm{Mg}-\mathrm{Fe}^{2+}$ exchange. Geochim. Cosmochim. Acta 1984, 48, 2597-2611. [CrossRef]

78. Mallmann, G.; O'Neill, H.S.C. The crystal/melt partitioning of V during mantle melting as a function of oxygen fugacity compared with some other elements (Al, P, Ca, Sc, Ti, Cr, Fe, Ga, Y, Zr and Nb). J. Petrol. 2009, 50, 1765-1794. [CrossRef]

79. Wijbrans, C.H.; Klemme, S.; Berndt, J.; Vollmer, C. Experimental determination of trace element partition coefficients between spinel and silicate melt: The influence of chemical composition and oxygen fugacity. Contrib. Mineral. Petrol. 2015, 169, 1-33. [CrossRef]

80. Burns, R.G. Crystal field effects in chromium and its partitioning in the mantle. Geochim. Cosmochim. Acta 1975, 39, 857-864. [CrossRef]

81. Sutton, S.R.; Jones, K.W.; Gordon, B.; Rives, M.L.; Bajt, S.; Smith, J.V. Reduced chromium in olivine grains from lunar basalt 15555: X-ray absorption near edge structure (XANES). Geochim. Cosmochim. Acta 1993, 57, 461-468. [CrossRef]

82. Jurewicz, A.J.G.; Watson, E.B. Cations in olivine, Part 2: Diffusion in olivine xenocrysts, with applications to petrology and mineral physics. Contrib. Mineral. Petrol. 1988, 99, 186-201. [CrossRef]

83. Zhou, Y.; Steele, I.M. Chemical zoning and diffusion of $\mathrm{Ca}, \mathrm{Al}, \mathrm{Mn}$, and $\mathrm{Cr}$ in olivine of Springwater pallasite. Lunar Planet. Sci. Conf. 1993, 24, 1573-1574.

84. Scowen, P.A.H.; Roeder, P.L.; Helz, R.T. Re-equilibration of chromite within Kilauea Iki lava lake, Hawaii. Contrib. Mineral. Petrol. 1991, 107, 8-20. [CrossRef]

85. Roeder, P.L.; Campbell, I.H.; Jamieson, H.E. A re-evaluation of the olivine-spinel geothermometer. Contrib. Mineral. Petrol. 1979, 68, 325-334. [CrossRef] 
86. Kröner, A.; Wilde, S.A.; Li, J.H.; Wang, K.Y. Age and evolution of a late Archaean to early Palaeozoic upper to lower crustal section in the Wutaishan-Hengshan-Fuping terrain of northern China. J. Asian Earth Sci. 2005, 24, 577-595. [CrossRef]

87. Faure, M.; Trap, P.; Lin, W.; Monie, P.; Bruguier, O. Polyorogenic evolution of the Paleoproterozoic Trans-North China Belt, new insights from the Lüliangshan-Hengshan-Wutaishan and Fuping massifs. Episodes 2007, 30, 95-106.

88. Zhao, G.C.; Cawood, P.A.; Wilde, S.A.; Lu, L.Z. Metamorphism of basement rocks in the Central Zone of the North China Craton: Implications for Paleoproterozoic tectonic evolution. Precambrian Res. 2000, 103, 55-88. [CrossRef]

89. Zhang, J.S.; Dirks, H.G.M.; Passchier, C.W. Extensional collapse and uplift in a polymetamorphic granulite terrain in the Archean and Paleoproterozoic of North China. Precambrian Res. 1994, 67, 3-15.

90. Zhai, M.G.; Guo, J.H.; Yan, Y.H. Discovery and preliminary study of the Archean high-pressure granulites in the North China. Sci. China B 1992, 12, 1325-1330.

91. Zhao, G.C.; Wilde, S.A.; Cawood, P.A.; Lu, L.Z. Petrology and P-T path of the Fuping mafic granulites: Implications for tectonic evolution of the central zone of the North China Craton. J. Met. Geol. 2000, 18, 375-391. [CrossRef]

92. Guo, J.H.; Zhai, M.G. Sm-Nd age dating of high-pressure granulites and amphibolites from Sanggan area, North China Craton. Chin. Sci. Bull. 2001, 46, 106-111. [CrossRef]

93. Guo, J.H.; O'Brien, P.J.; Zhai, M.G. High-pressure granulites in the Sangan area, North China Craton: Metamorphic evolution, P-T paths and geotectonic significance. J. Met. Geol. 2002, 20, 741-756. [CrossRef]

94. Guo, J.H.; Sun, M.; Zhai, M.G. Sm-Nd and SHRIMP U-Pb zircon geochronology of high-pressure granulites in the Sanggan area, North China Craton: Timing of Paleoproterozoic continental collision. J. Asian Earth Sci. 2005, 24, 629-642. [CrossRef]

95. Yu, J.H.; Wang, D.Z.; Wang, X.Y. Ages of the Luliang Group and its main metamorphism in the Luliang Mountains, Shank evidence from single-grain zircon U-Pb ages. Geol. Rev. 1997, 43, 403-408.

96. Peng, P.; Zhai, M.G.; Zhang, H.F.; Guo, J.H. Geochronological constraints on the Paleoproterozoic evolution of the North China craton: SHRIMP zircon ages of different types of mafic dikes. Int. Geol. Rev. 2005, 47, 492-508. [CrossRef]

97. Yokoyama, K. Nikubuchi peridotite body in the Sanbagawa metamorphic belt; thermal history of the "Al-pyroxene-rich suite" peridotite body in high pressure metamorphic terrain. Contrib. Mineral. Petrol. 1980, 73, 1-13. [CrossRef]

98. Gargiulo, M.F.; Bjerg, E.A.; Mogessie, A. Spinel group minerals in metamorphosed ultramafic rocks from Rio de Las Tunas Belt, Central Andes, Argentina. Geol. Acta 2013, 11, 133-148.

99. Lenaz, D.; Velicogna, M.; Halenius, U.; O'Driscoll., B. Structural parameters of Cr-bearing spinels and pleonaste from the Cuillin Igneous Complex (Isle of Skye, Scotland): Implications for metamorphic and cooling history. Mineral. Mag. 2016, 80, 749-764. [CrossRef]

100. Roeder, P.L. Chromite from the fiery rain of chondrules to the Kilauea Iki lava lake. Can. Mineral. 1994, 32, 729-746.

101. González-Jiménez, J.M.; Reich, M.; Camprubí, A.; Gervilla, F.; Griffin, W.L.; Colás, V.; O’Reilly, S.Y.; Proenza, A.J.; Pearson, N.J.; Centeno-García, E. Thermal metamorphism of mantle chromites and the stability of noble-metal nanoparticles. Contrib. Mineral. Petrol. 2015, 170, 15. [CrossRef]

102. Mussallam, K.; Jung, D.; Burgath, K. Textural features and chemical characteristics of chromites in ultramafic rocks, Chalkidiki complex (Northeastern Greece). Tschermaks Mineralogische und Petrographische Mitteilungen 1981, 29, 75-101. [CrossRef]

103. Arai, S.; Uesugi, J.; Ahmed, A.H. Upper Crustal Podiform Chromitite from the Northern Oman Ophieolite as the Stratigraphically Shallowest Chromitite in Ophiolite and Its Implication for Cr Concentration. Contrib. Mineral. Petrol. 2004, 147, 145-154. [CrossRef]

(c) 2018 by the authors. Licensee MDPI, Basel, Switzerland. This article is an open access article distributed under the terms and conditions of the Creative Commons Attribution (CC BY) license (http:// creativecommons.org/licenses/by/4.0/). 